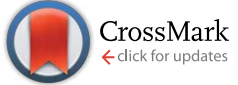

Cite this: RSC Adv., 2017, 7, 1484

Received 7th November 2016

Accepted 20th December 2016

DOI: $10.1039 / c 6 r a 26435 b$

www.rsc.org/advances

\section{A practical iodine-catalyzed oxidative conversion of aldehydes to nitriles $\uparrow$}

\author{
Chaojie Fang, Meichao Li, ${ }^{*}$ Xinquan Hu, Weimin Mo, Baoxiang Hu, Nan Sun, Liqun Jin \\ and Zhenlu Shen*
}

A simple and efficient method for the direct synthesis of nitriles from aldehydes using ammonium acetate as the nitrogen source has been developed. The reactions were performed with iodine as the catalyst and tertbutyl hydroperoxide (TBHP) as the oxidant under mild conditions. A variety of aromatic, heteroaromatic, aliphatic and allylic aldehydes could be converted into their corresponding nitriles in good to excellent yields.

\section{Introduction}

Nitriles are important starting materials for the synthesis of amides, ${ }^{1-3}$ amines, ${ }^{4,5}$ ketones, ${ }^{6,7}$ carbonic acids ${ }^{8,9}$ and esters. ${ }^{10,11}$ Furthermore, the cyano group is a key motif in the structure of numerous useful compounds, such as bioactive natural products, pharmaceuticals ${ }^{12,13}$ and functional materials. ${ }^{14}$ Traditionally, the Sandmeyer ${ }^{15}$ and Rosenmund-von Braun reaction ${ }^{16}$ were widely used in synthesizing aryl nitriles, while highly toxic cyanide salts, were always required and the reactions produced large amounts of inorganic salts as waste. Therefore, the development of new pathways for the synthesis of nitriles has gained increasing attention. In the past decades, a large number of new methods utilizing different kinds of compounds, like alcohols, ${ }^{17-21}$ amines, ${ }^{22-25}$ amides $^{26-28}$ and aldoximes ${ }^{29,30}$ as starting materials have been reported. These methods offer great improvements, but always need high temperature or pressure, stoichiometric or excess amount of highly reactive oxidants, transition metal catalysts or metal complex catalysts.

Aldehydes have been utilized as attractive starting materials for the synthesis of nitriles due to their ready availability, and several methods have been reported with different compounds as nitrogen sources. ${ }^{31-42}$ Inevitably, there were some drawbacks existing in these methods: (i) high reaction temperature was still needed; (ii) stoichiometric halogen-containing or metal oxidants were always required; (iii) limited substrate scopes; (iv) transition metal catalysts were essential in most cases.

Metal-free catalysis in modern organic synthesis has received much attention because of its economy and low toxicity. The $\mathrm{I}_{2} /$ tert-butyl hydroperoxide (TBHP) catalytic oxidation system is one of the most popular examples. TBHP is a kind of mild,

College of Chemical Engineering, Zhejiang University of Technology, Hangzhou 310014, China.E-mail: zhenlushen@zjut.edu.cn; limc@zjut.edu.cn

$\uparrow$ Electronic supplementary information (ESI) available: Experimental procedure and copies of ${ }^{1} \mathrm{H}$ NMR spectra. See DOI: 10.1039/c6ra26435b efficient and manageable oxidant, giving tert-butanol as the benign by-product in most cases. Recently, the $\mathrm{I}_{2} / \mathrm{TBHP}$ system has been widely used in oxidative reactions, such as $\mathrm{C}-\mathrm{C}$ bond cleavage, ${ }^{43}$ oxidation of indoles, ${ }^{44}$ oxidative coupling reaction ${ }^{45}$ and oxidative cyclization, ${ }^{46}$ etc. Reddy and co-workers ${ }^{47}$ reported a $\mathrm{KI} / \mathrm{I}_{2}-\mathrm{TBHP}$ system for the conversion of alcohols, aldehydes and amines into nitriles. Under this catalytic system, they prepared a series of aromatic nitriles from aromatic aldehydes by using ammonia as the nitrogen source in water. However, the yields of products were general low and the nitro-substituted substrate cannot be converted into the desired product. What's more, the large excess of ammonia may cause environmental problems as a result of its easy volatility and would be an undesirable contaminant in waste water.

Ammonium acetate $\left(\mathrm{NH}_{4} \mathrm{OAc}\right)$, which has many remarkable advantages, including good stability and low toxicity, is an idea low-cost alternative nitrogen source instead of ammonia. Previously, ammonium acetate as the cyanide source has already been developed in the direct synthesis of nitriles from aldehydes, like $\mathrm{NH}_{4} \mathrm{OAc} / \mathrm{HTIB}^{48}$ and $\mathrm{NH}_{4} \mathrm{OAc} / \mathrm{PPTB}^{49}$ systems. One of limitations of these examples is the use of expensive halogen-containing oxidants, which could generate hazardous

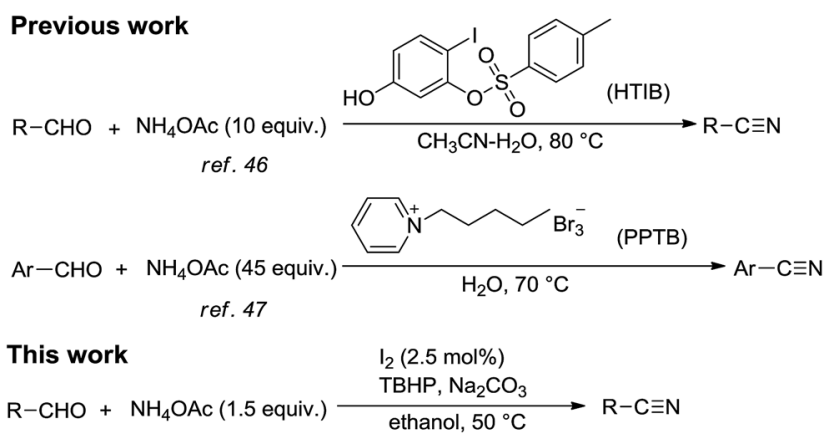

Scheme 1 The improved method for the synthesis of nitriles from aldehydes with $\mathrm{NH}_{4} \mathrm{OAc}$ as a nitrogen source. 
wastes during work-up. On the other hand, about decade times of $\mathrm{NH}_{4} \mathrm{OAc}$ had to be employed to ensure the full conversion of aldehydes, which is extremely wasteful.

Inspired by hereinbefore work, as a part of our research program aimed at synthesis of nitriles and $\mathrm{I}_{2}$-catalyzed reaction, ${ }^{50-52}$ we attempted to develop a simple, efficient, economical and environmentally friendly method for the direct synthesis of nitriles from aldehydes using $\mathrm{NH}_{4} \mathrm{OAc}$ as the nitrogen source under $\mathrm{I}_{2} / \mathrm{TBHP}$ system (Scheme 1).

\section{Results and discussion}

At the outset, benzaldehyde (1a) was chosen as the model substrate to examine a variety of reaction condition parameters and the results are summarized in Table 1. Firstly, a series of solvents were screened and the results indicated 1a could be transformed to benzonitrile (1b) in $86 \%$ yield in ethanol within $8 \mathrm{~h}$ at $60{ }^{\circ} \mathrm{C}$ (entry 4). As is known to all, water is an ideal solvent. We have also tried to verify the feasibility of using water as the solvent. Unfortunately, the easy formation of amide in aqueous medium resulted in a low yield of nitrile (35\%) (entry 8). Then 1.5 equiv. of $\mathrm{K}_{2} \mathrm{CO}_{3}$ as acid-binding agent was tentatively added into the reaction, and $\mathbf{1 a}$ was almost completely converted into 1b in 2.5 h (entry 9). Some other acid-binding agents, such as $\mathrm{NaHCO}_{3}, \mathrm{NaOAc}, \mathrm{Na}_{2} \mathrm{CO}_{3}$ (entries 10-12), were also tested. Gratifyingly, the reaction could be performed more smoothly in the presence of $\mathrm{Na}_{2} \mathrm{CO}_{3}$ (entry 12).
When the loading of $\mathrm{Na}_{2} \mathrm{CO}_{3}$ was reduced to 1.0 equiv. and 0.5 equiv., the reaction time had to be prolonged to $2.5 \mathrm{~h}$ and $8 \mathrm{~h}$, respectively (entries 13 and 14). Thus, we chose to add 1.0 equiv. of $\mathrm{Na}_{2} \mathrm{CO}_{3}$ into the reaction system. When the loading of $\mathrm{I}_{2}$ was reduced to $2.5 \mathrm{~mol} \%, \mathbf{1 b}$ could be obtained in $99 \%$ yield in $5 \mathrm{~h}$ (entry 15). After that, the reaction temperature was decreased and we found that $\mathbf{1 b}$ could be obtained in $99 \%$ yield at $50{ }^{\circ} \mathrm{C}$ in $5.5 \mathrm{~h}$ (entries 17 and 18). At last, when the loading of $\mathrm{NH}_{4} \mathrm{OAc}$ was reduced to 1.5 equiv., 1a could also be converted into $\mathbf{1 b}$ successfully with high yield in $6 \mathrm{~h}$ (entry 19).

Having defined the optimum conditions for the reaction, the substrate scope of this methodology was investigated and the results are summarized in Scheme 2. Initially, the catalytic system was examined to tolerate a wide range of aromatic aldehydes which bearing electron-withdrawing or electron-donating groups on benzene ring. It was observed that substrates carrying electron-withdrawing groups could be smoothly converted into the desired products in $5 \mathrm{~h}(\mathbf{2 b}-\mathbf{9 b})$. Benzaldehydes carrying electron-donating groups, need much more time to complete their transformation $(\mathbf{1 0 b}-\mathbf{1 7 b})$. The $\mathrm{I}_{2}-\mathrm{TBHP}$ catalytic system was also tolerant of substrates containing heteroatoms such as oxygen, sulfur and nitrogen. In the case of 20a and 22a, the conversions could perform smoothly in $5 \mathrm{~h}$ (20b and 22b). However, in the case of electron-rich heteroaromatic aldehydes containing $\mathrm{N}$ and $\mathrm{S}$ atoms, prolonged time was needed for full conversions (19b and 21b). In addition, the representative

Table 1 Optimization of $\mathrm{I}_{2}$-TBHP catalytic system for the direct synthesis of benzonitrile from benzaldehyde ${ }^{a}$

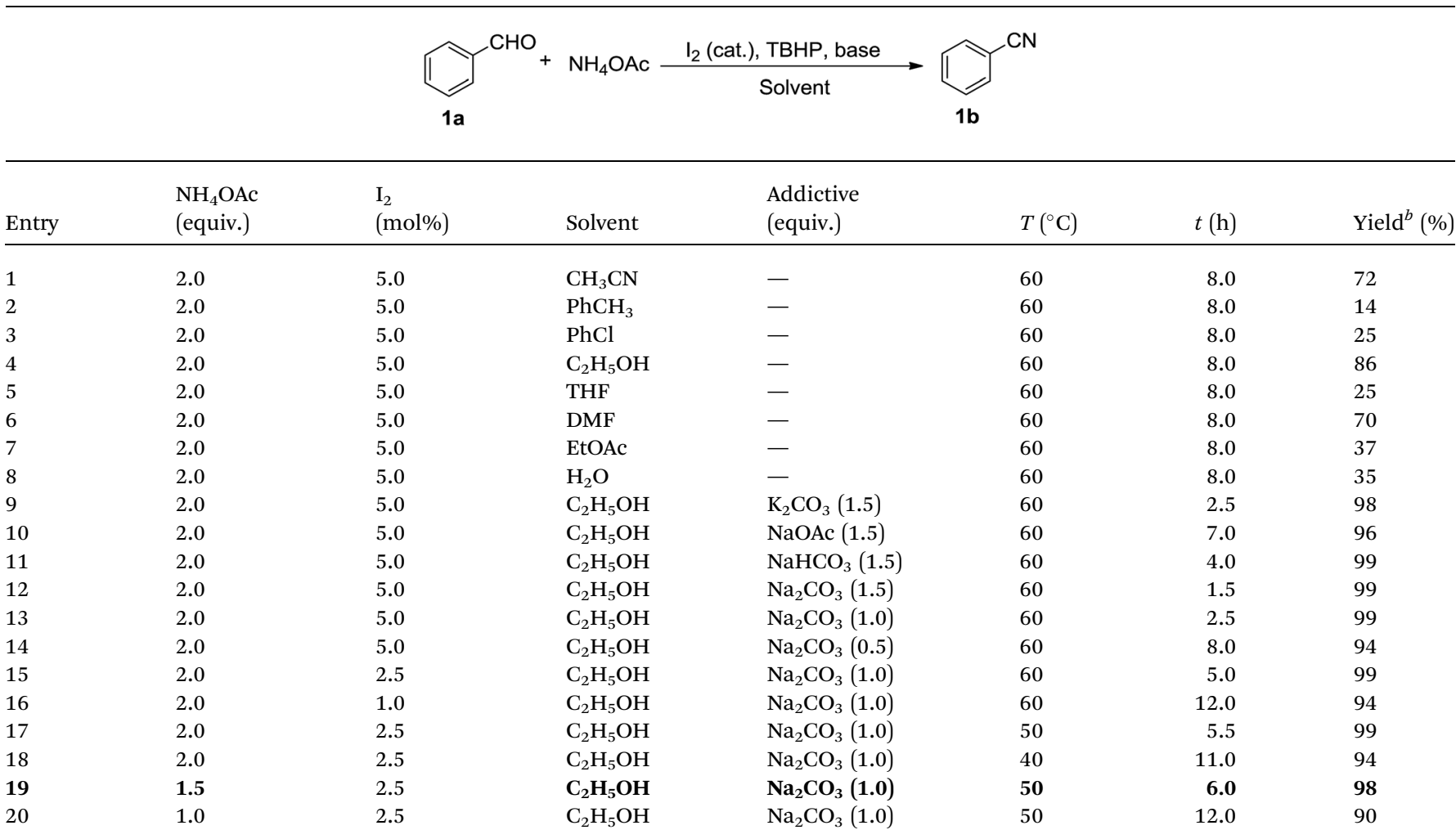

${ }^{a}$ Reaction conditions: $1 \mathrm{a}(4 \mathrm{mmol}, 0.424 \mathrm{~g}), 5 \mathrm{~mL}$ of solvents, 1.1 equiv. of TBHP. ${ }^{b}$ Yields were determined by GC using an internal standard method. 


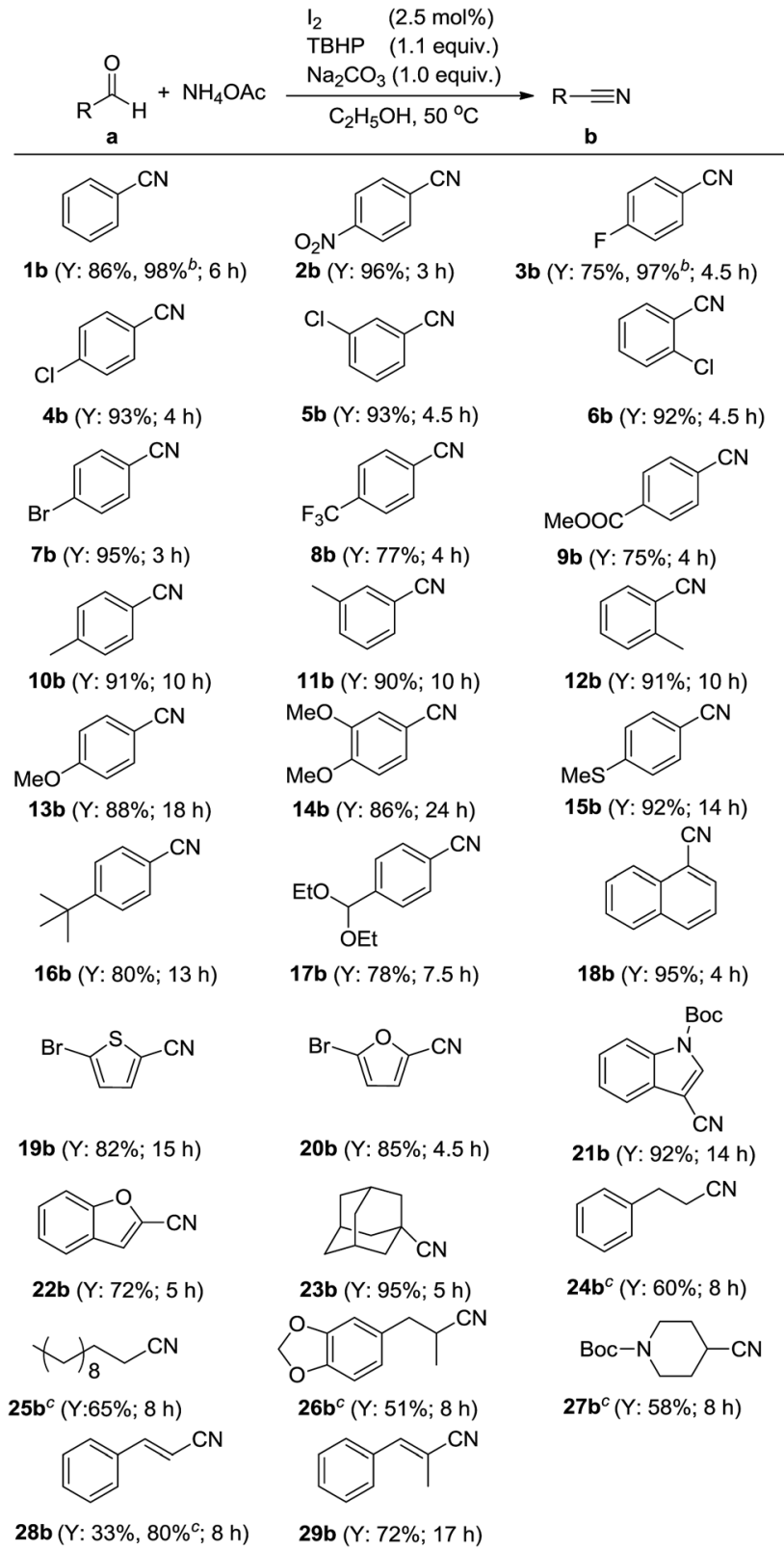

Scheme 2 Oxidative conversion of aldehydes to nitriles ${ }^{a} .{ }^{a}$ Reaction conditions: aldehyde (4 mmol), $\mathrm{NH}_{4} \mathrm{OAc}$ (1.5 equiv.), $\mathrm{I}_{2}$ (2.5 mol\%), TBHP (1.1 equiv.), $5 \mathrm{~mL}$ of ethanol, $50{ }^{\circ} \mathrm{C} . \mathrm{Y}$ = yield of the isolated product. ${ }^{b}$ Yields were determined by GC using an internal standard method. ${ }^{c}$ Aldehyde was slowly added into reaction solution.

polycyclic substrate, 1-naphthaldehyde (18a) tolerated our catalytic system to give the product $\mathbf{1 8 b}$ in excellent yield.

Adamantane-1-carbaldehyde (23a), an $\alpha$-saturated aliphatic aldehyde, gave the desired nitrile $\mathbf{2 3 b}$ in $94 \%$ yield. As is known to all, aldehydes with $\alpha-\mathrm{H}$ atoms can be halogenated at their $\alpha$ positions by reaction with halogens, like $\mathrm{Cl}_{2}, \mathrm{Br}_{2}$ and $\mathrm{I}_{2}$. This conclusion was proved by the representative aliphatic aldehyde 3-phenylpropanal (24a). When it was used as the substrate, the yield of 3-phenylpropanenitrile (24b) was very low. However, when aldehyde $\mathbf{2 4 a}$ was slowly added into the reaction solution, $60 \%$ yield of $24 \mathrm{~b}$ could be obtained. This consequence suggested there was a competitive relationship between the halogenated reaction and the desired reaction.

With this encouraging finding in hand, some other $\alpha$ unsaturated aldehydes, such as undecanal (25a), helional (26a) and $N$-Boc-piperidin-4-ylformaldehyde (27a) were also examined in this modified method. To our delight, all of them could be converted into the desired nitriles with satisfying yields. At last, two allylic aldehydes, cinnamaldehyde (28a) and (E)-2methyl-3-phenylacrylaldehyde (29a) also tolerated our catalytic system. Cinnamonitrile (28b) could be obtained in $80 \%$ yield under optimized and modified conditions.

In addition, this catalytic system could also be applied in the synthesis of a complex compound (30b) (eqn (1)), which displays appreciable anti-inflammatory and selective COX-2 inhibitory activity. ${ }^{51}$ Because of the poor solubility of 30a in ethanol, equal volume of DMF was chosen as the solvent in the transformation of 30a to 30b. To our delight, the reaction was smoothly performed and $84 \%$ yield of $30 \mathrm{~b}$ was obtained.

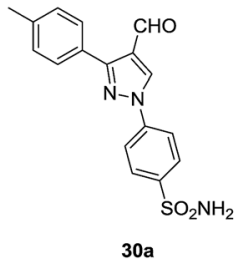

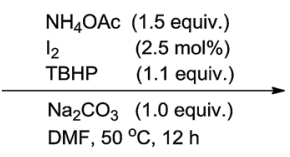

DMF, $50^{\circ} \mathrm{C}, 12 \mathrm{~h}$
In order to examine the practicability of this catalytic system, gram-scale reaction was also performed under the optimized conditions (14.8 $\mathrm{g}$ of 4-bromobenzaldehyde (7a)). It was gratifying that the isolated product $13.5 \mathrm{~g}$ of 4-bromobenzonitrile (7b) could be obtained ( $93 \%$ yield).

Next, we envisioned oxidative conversion of primary alcohol to nitrile using our method (eqn (2)). However, the oxidative conversion of benzyl alcohol under the optimized conditions gave only $1 \mathrm{~b}$ in $58 \%$ yield after $24 \mathrm{~h}$ although the loading of TBHP was increased to 2.5 equiv. A large amount of benzyl alcohol was remained, which cannot be converted into the desired product.

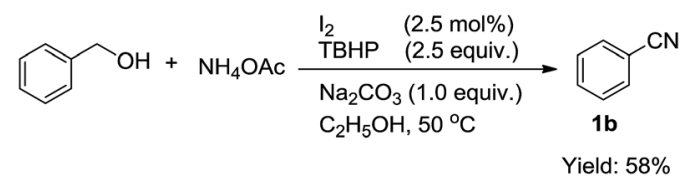

With these results in hand, we tried to explore the plausible reaction mechanism. When $4 \mathrm{mmol}$ of benzaldehyde (1a), 1.5 equiv. of $\mathrm{NH}_{4} \mathrm{OAc}, 1.0$ equiv. of $\mathrm{Na}_{2} \mathrm{CO}_{3}$ and $5 \mathrm{~mL}$ of ethanol were mixed up and stirred under $50{ }^{\circ} \mathrm{C}$ for $8 \mathrm{~h}$, phenylmethanimine was achieved in $13 \%$ yield determined by GC with the normalization method. Then $2.5 \mathrm{~mol} \%$ of $\mathrm{I}_{2}$ and 1.1 equiv. of TBHP were added into the reaction mixture, it was founded that benzonitrile (1b) was the sole product after $6 \mathrm{~h}$. These results implied that: (i) phenylmethanimine was the intermediate product; (ii) the process of transformation phenylmethanimine into $\mathbf{1 b}$ could promote the generation of phenylmethanimine from $\mathbf{1 a}$. 


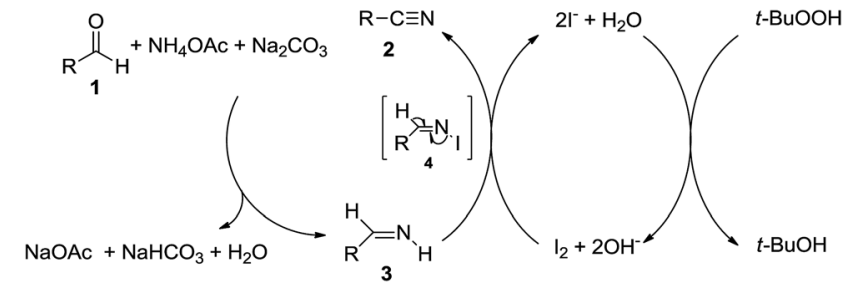

Scheme 3 A plausible reaction mechanism.

According to literatures and our observations, a plausible reaction mechanism of this $\mathrm{I}_{2} / \mathrm{TBHP}$ catalytic system has been proposed in Scheme 3. First of all, aldehyde reacted with ammonium acetate to form aldimine 3 and sodium acetate in the presence of $\mathrm{Na}_{2} \mathrm{CO}_{3}$. Then aldimine 3 was oxidized by $\mathrm{I}_{2}$, affording $N$-iodo aldimine 4 as an intermediate, which was transformed into nitrile 2 by $\beta$-elimination of HI under alkaline condition. At the same time, $\mathrm{I}^{-}$was oxidized to $\mathrm{I}_{2}$ by TBHP, which was reduced to tert-butanol immediately.

\section{Conclusion}

In conclusion, we have successfully developed a simple and efficient method for the direct synthesis of nitriles from aldehydes with ammonium acetate as the nitrogen source, using $\mathrm{I}_{2}$ as the catalyst and TBHP as the oxidant. This catalytic system is practical, environmentally friendly as it utilizes ethanol as solvent and TBHP as oxidant. A broad range of substrates including aromatic, heteroaromatic, aliphatic and allylic nitriles could be obtained in good to excellent yields.

\section{Experimental section}

General procedure for the synthesis of $1 b-23 b, 29 b$ and $30 b$

To a $20 \mathrm{~mL}$, two-necked, round-bottom flask equipped with a magnetic stirring bar and a thermometer, were added $4 \mathrm{mmol}$ of aldehyde, $0.462 \mathrm{~g}(6 \mathrm{mmol})$ of ammonium acetate, $0.424 \mathrm{~g}$ ( 4 $\mathrm{mmol}$ ) of $\mathrm{Na}_{2} \mathrm{CO}_{3}, 25.4 \mathrm{mg}(0.1 \mathrm{mmol})$ of $\mathrm{I}_{2}, 0.61 \mathrm{~g}$ of TBHP (wt\% $=65,1.1$ equiv.) and $5 \mathrm{~mL}$ of ethanol (replaced by $5 \mathrm{~mL}$ of DMF for 30a). Then the flask was sealed by a bubbler and placed into a preheated oil bath $\left(50^{\circ} \mathrm{C}\right)$. After the reaction was finished (as determined by GC, except 30a which was determined by HPLC), to the reaction mixture were added $10 \mathrm{~mL}$ of $5 \%$ of $\mathrm{Na}_{2} \mathrm{~S}_{2} \mathrm{O}_{3}$ solution and stirred for $15 \mathrm{~min}$. Then the mixture was transferred into a separation funnel, and $100 \mathrm{~mL}$ of diethyl ether (replaced by $100 \mathrm{~mL}$ of dichloromethane for $\mathbf{3 0 b}$ ) were also added to the separation funnel. The two-phase mixture was washed with saturated sodium bicarbonate solution $(25 \mathrm{~mL} \times$ 2). Then the organic layer was dried with $\mathrm{Na}_{2} \mathrm{SO}_{4}$, concentrated on a rotary evaporator and the residue was purified by column chromatography on silica gel using hexanes/EtOAc as eluent to afford the pure product.

\section{General procedure for the synthesis of $24 b-28 b$}

To a $20 \mathrm{~mL}$, two-necked, round-bottom flask equipped with a magnetic stirring bar and a thermometer, were added $0.462 \mathrm{~g}$
(6 mmol) of ammonium acetate, $0.424 \mathrm{~g}(4 \mathrm{mmol})$ of $\mathrm{Na}_{2} \mathrm{CO}_{3}$, $25.4 \mathrm{mg}(0.1 \mathrm{mmol})$ of $\mathrm{I}_{2}, 0.61 \mathrm{~g}$ of TBHP $(\mathrm{wt} \%=65 \%, 1.1$ equiv.) and $5 \mathrm{~mL}$ of ethanol. Then the flask was sealed by a rubber plug and placed into a preheated oil bath $\left(50{ }^{\circ} \mathrm{C}\right)$. After that, $4 \mathrm{mmol}$ of aldehyde, which was distilled to $1 \mathrm{~mL}$ with ethanol, was injected into the solution slowly $(4 \mathrm{~h})$. The work-up procedure was as same as that for the synthesis of 1b-24b.

Benzonitrile (1b). Colorless oil; ${ }^{1} \mathrm{H}$ NMR $\left(500 \mathrm{MHz}, \mathrm{CDCl}_{3}\right)$ $\delta$ 7.66-7.63 (m, 2H), 7.62-7.59 (m, 1H), 7.49-7.46 (m, 2H); MS: $\mathrm{m} / \mathrm{z}=103.0\left[\mathrm{M}^{+}\right]$.

4-Nitrobenzonitrile (2b). Pale yellow solid; $\mathrm{mp}$ : 146.3$148.7{ }^{\circ} \mathrm{C} ;{ }^{1} \mathrm{H}$ NMR $\left(500 \mathrm{MHz}, \mathrm{CDCl}_{3}\right) \delta 8.39-8.36(\mathrm{~m}, 2 \mathrm{H}), 7.91-$ $7.90(\mathrm{~m}, 2 \mathrm{H})$; MS: $m / z=148.0\left[\mathrm{M}^{+}\right]$.

4-Fluorobenzonitrile (3b). White solid; mp: $32.7-34.1{ }^{\circ} \mathrm{C} ;{ }^{1} \mathrm{H}$ NMR $\left(500 \mathrm{MHz}, \mathrm{CDCl}_{3}\right) \delta$ 7.71-7.67 (m, 2H), 7.21-7.16 (m, 2H); MS: $m / z=121.0\left[\mathrm{M}^{+}\right]$.

4-Chlorobenzonitrile (4b). White solid; mp: $93.1-94.7^{\circ} \mathrm{C} ;{ }^{1} \mathrm{H}$ NMR $\left(500 \mathrm{MHz}, \mathrm{CDCl}_{3}\right) \delta 7.62-7.60(\mathrm{~m}, 2 \mathrm{H}), 7.50-7.47(\mathrm{~m}, 2 \mathrm{H})$; MS: $m / z=137.0\left[\mathrm{M}^{+}\right]$.

3-Chlorobenzonitrile (5b). White solid; mp: $44.0-45.8{ }^{\circ} \mathrm{C} ;{ }^{1} \mathrm{H}$ NMR $\left(500 \mathrm{MHz}, \mathrm{CDCl}_{3}\right) \delta 7.65(\mathrm{t}, J=1.7 \mathrm{~Hz}, 1 \mathrm{H}), 7.61-7.59(\mathrm{~m}$, $1 \mathrm{H}), 7.58-7.56(\mathrm{~m}, 1 \mathrm{H}), 7.45(\mathrm{t}, J=15.8 \mathrm{~Hz}, 2 \mathrm{H}) ; \mathrm{MS}: \mathrm{m} / z=137.0$ $\left[\mathrm{M}^{+}\right]$.

2-Chlorobenzonitrile (6b). White solid; mp: $37.5-40.3{ }^{\circ} \mathrm{C} ;{ }^{1} \mathrm{H}$ NMR $\left(500 \mathrm{MHz}, \mathrm{CDCl}_{3}\right) \delta 7.70-7.68(\mathrm{~m}, 1 \mathrm{H}), 7.58-7.52(\mathrm{~m}, 2 \mathrm{H})$, 7.41-7.38 (m, 1H); MS: $m / z=137.0\left[\mathrm{M}^{+}\right]$.

4-Bromobenzonitrile (7b). White solid; mp: $109.6-112.4{ }^{\circ} \mathrm{C}$; ${ }^{1} \mathrm{H}$ NMR $\left(500 \mathrm{MHz}, \mathrm{CDCl}_{3}\right) \delta$ 7.66-7.64 (m, 2H), 7.55-7.53 (m, 2H); MS: $m / z=180.9\left[\mathrm{M}^{+}\right]$.

4-(Trifluoromethyl)benzonitrile (8b). White solid; mp: 40.6$42.8{ }^{\circ} \mathrm{C} ;{ }^{1} \mathrm{H}$ NMR $\left(500 \mathrm{MHz}, \mathrm{CDCl}_{3}\right) \delta 7.82-7.81(\mathrm{~d}, 2 \mathrm{H}, J=8.1$ $\mathrm{Hz}), 7.76(\mathrm{~d}, 2 \mathrm{H}, J=8.3 \mathrm{~Hz})$; MS: $m / z=171.1\left[\mathrm{M}^{+}\right]$.

Methyl 4-cyanobenzoate (9b). White solid; $\mathrm{mp}$ : $60.0-61.5^{\circ} \mathrm{C}$; ${ }^{1} \mathrm{H}$ NMR $\left(500 \mathrm{MHz}, \mathrm{CDCl}_{3}\right) \delta 8.16-8.14(\mathrm{~m}, 2 \mathrm{H}), 7.77-7.75(\mathrm{~m}$, $2 \mathrm{H}), 3.97$ (s, 3H); MS: $m / z=161.1\left[\mathrm{M}^{+}\right]$.

4-Methylbenzonitrile (10b). Colorless oil; ${ }^{1} \mathrm{H}$ NMR $(500 \mathrm{MHz}$, $\left.\mathrm{CDCl}_{3}\right) \delta 7.54(\mathrm{~d}, 2 \mathrm{H}, J=8.2 \mathrm{~Hz}), 7.27(\mathrm{~d}, 2 \mathrm{H}, J=8.0 \mathrm{~Hz}), 2.42(\mathrm{~s}$, $3 \mathrm{H})$; MS: $m / z=117.1\left[\mathrm{M}^{+}\right]$.

3-Methylbenzonitrile (11b). Colorless oil; ${ }^{1} \mathrm{H}$ NMR $(500 \mathrm{MHz}$, $\left.\mathrm{CDCl}_{3}\right) \delta 7.44(\mathrm{~d}, J=6.5 \mathrm{~Hz}, 2 \mathrm{H}), 7.40(\mathrm{~d}, J=7.6 \mathrm{~Hz}, 1 \mathrm{H}), 7.36-$ $7.33(\mathrm{~m}, 1 \mathrm{H})$; MS: $m / z=117.1\left[\mathrm{M}^{+}\right]$.

2-Methylbenzonitrile (12b). Colorless oil; ${ }^{1} \mathrm{H}$ NMR $(500 \mathrm{MHz}$, $\left.\mathrm{CDCl}_{3}\right) \delta 7.56(\mathrm{~d}, J=7.7 \mathrm{~Hz}, 1 \mathrm{H}), 7.48-7.45(\mathrm{~m}, 2 \mathrm{H}), 7.30(\mathrm{~d}, 1 \mathrm{H}, J$ $=7.8 \mathrm{~Hz}), 7.26(\mathrm{t}, 1 \mathrm{H}, J=14.8 \mathrm{~Hz}), 2.53(\mathrm{~s}, 1 \mathrm{H})$; MS: $m / z=117.1$ $\left[\mathrm{M}^{+}\right]$.

4-Methoxybenzonitrile (13b). White solid; mp: $58.2-60.3{ }^{\circ} \mathrm{C}$; ${ }^{1} \mathrm{H}$ NMR $\left(500 \mathrm{MHz}, \mathrm{CDCl}_{3}\right) \delta$ 7.60-7.58 (m, 2H), 6.97-6.94 (m, $2 \mathrm{H}), 3.86$ (s, 3H); MS: $m / z=133.0\left[\mathrm{M}^{+}\right]$.

3,4-Dimethoxybenzonitrile (14b). White solid; mp: 64.9$66.4{ }^{\circ} \mathrm{C} ;{ }^{1} \mathrm{H}$ NMR $\left(500 \mathrm{MHz}, \mathrm{CDCl}_{3}\right) \delta 7.30-7.28(\mathrm{~m}, 1 \mathrm{H}), 7.09(\mathrm{~d}$, $1 \mathrm{H}, J=1.9 \mathrm{~Hz}), 6.90(\mathrm{~d}, 2 \mathrm{H}, J=8.3 \mathrm{~Hz}), 3.91(\mathrm{~s}, 3 \mathrm{H}), 3.88(\mathrm{~s}, 3 \mathrm{H})$; MS: $m / z=163.1\left[\mathrm{M}^{+}\right]$.

4-(Methylthio)benzonitrile (15b). White solid; mp: 59.7$62.2{ }^{\circ} \mathrm{C} ;{ }^{1} \mathrm{H}$ NMR $\left(500 \mathrm{MHz}, \mathrm{CDCl}_{3}\right) \delta 7.55-7.53(\mathrm{~m}, 2 \mathrm{H}), 7.28-$ $7.26(\mathrm{~m}, 2 \mathrm{H}), 2.52(\mathrm{~s}, 3 \mathrm{H})$; MS: $m / z=149.0\left[\mathrm{M}^{+}\right]$. 
4-(tert-Butyl)benzonitrile (16b). Pale yellow oil; ${ }^{1} \mathrm{H}$ NMR $(500$ $\left.\mathrm{MHz}, \mathrm{CDCl}_{3}\right) \delta$ 7.61-7.59 (m, 2H), 7.51-7.48 (m, 2H), $1.34(\mathrm{~s}$, 9H); MS: $m / z=159.1\left[\mathrm{M}^{+}\right]$.

4-(Diethoxymethyl)benzonitrile (17b). Colorless oil; ${ }^{1} \mathrm{H}$ NMR $\left(500 \mathrm{MHz}, \mathrm{CDCl}_{3}\right) \delta 7.60(\mathrm{dd}, J=24.0,7.4 \mathrm{~Hz}, 1 \mathrm{H}), 5.51(\mathrm{~s}, 1 \mathrm{H})$, 3.61-3.49 (m, 4H), $1.21(\mathrm{t}, 6 \mathrm{H}, J=6.6 \mathrm{~Hz})$; MS: $m / z=205.1\left[\mathrm{M}^{+}\right]$.

1-Naphthonitrile (18b). Pale yellow oil; ${ }^{1} \mathrm{H}$ NMR $(500 \mathrm{MHz}$, $\left.\mathrm{CDCl}_{3}\right) \delta 8.24-8.22(\mathrm{~m}, 1 \mathrm{H}), 8.07$ (d, $\left.J=8.3 \mathrm{~Hz}, 1 \mathrm{H}\right), 7.93-7.89$ $(\mathrm{m}, 2 \mathrm{H}), 7.70-7.67(\mathrm{~m}, 1 \mathrm{H}), 7.63-7.60(\mathrm{~m}, 1 \mathrm{H}), 7.53-7.50(\mathrm{~m}$, 1H); MS: $m / z=153.0\left[\mathbf{M}^{+}\right]$.

5-Bromothiophene-2-carbonitrile (19b). Pale yellow oil; ${ }^{1} \mathrm{H}$ NMR (500 MHz, $\left.\mathrm{CDCl}_{3}\right) \delta 7.39(\mathrm{~d}, J=4.0 \mathrm{~Hz}, 1 \mathrm{H}), 7.10(\mathrm{~d}, J=$ $4.0 \mathrm{~Hz}, 1 \mathrm{H})$; MS: $m / z=188.9\left[\mathrm{M}^{+}\right]$.

5-Bromofuran-2-carbonitrile (20b). Pale orange oil; ${ }^{1} \mathrm{H}$ NMR $\left(500 \mathrm{MHz}, \mathrm{CDCl}_{3}\right) \delta 7.07(\mathrm{~d}, J=3.6 \mathrm{~Hz}, 1 \mathrm{H}), 6.49(\mathrm{~d}, J=3.6 \mathrm{~Hz}$, $1 \mathrm{H})$; MS: $m / z=171.0\left[\mathrm{M}^{+}\right]$.

$\mathrm{N}$-Boc-3-indolecarbonitrile (21b). White solid; mp: 119.3$121.1{ }^{\circ} \mathrm{C} ;{ }^{1} \mathrm{H}$ NMR $\left(500 \mathrm{MHz}, \mathrm{CDCl}_{3}\right) \delta 8.20(\mathrm{~d}, J=8.3 \mathrm{~Hz}, 1 \mathrm{H})$, $8.13(\mathrm{~s}, 1 \mathrm{H}), 7.74(\mathrm{~d}, J=7.9 \mathrm{~Hz}, 1 \mathrm{H}), 7.47-7.44(\mathrm{~m}, 1 \mathrm{H}), 7.41-7.38$ (m, 1H), 1.71 (s, 9H); MS (ESI): $m / z=265.1\left[\mathrm{M}+\mathrm{Na}^{+}\right]$.

Benzofuran-2-carbonitrile (22b). Yellow oil; ${ }^{1} \mathrm{H}$ NMR $(500 \mathrm{MHz}$, $\left.\mathrm{CDCl}_{3}\right) \delta 7.70(\mathrm{~d}, J=7.9 \mathrm{~Hz}, 1 \mathrm{H}), 7.59-7.57(\mathrm{~m}, 1 \mathrm{H}), 7.55-7.51(\mathrm{~m}$, $1 \mathrm{H}), 7.48$ (d, $J=7.9 \mathrm{~Hz}, 1 \mathrm{H}), 7.40-7.37$ (m, 1H); MS: $m / z=143.0\left[\mathrm{M}^{+}\right]$.

Adamantane-1-carbonitrile (23b). White solid; mp: 185.2$191.2{ }^{\circ} \mathrm{C} ;{ }^{1} \mathrm{H}$ NMR $\left(500 \mathrm{MHz}, \mathrm{CDCl}_{3}\right) \delta 2.04(\mathrm{~d}, J=6.2 \mathrm{~Hz}, 9 \mathrm{H})$, 1.76-1.70 (m, 6H); MS: $m / z=161.1\left[\mathrm{M}^{+}\right]$.

3-Phenylpropanenitrile (24b). Pale yellow oil; ${ }^{1} \mathrm{H}$ NMR (500 $\left.\mathrm{MHz} \mathrm{CDCl}_{3}\right) \delta$ 7.39-7.36 (m, 2H), 7.32-7.29 (m, 1H), 7.27-7.25 $(\mathrm{m}, 2 \mathrm{H}), 2.96(\mathrm{t}, J=7.4 \mathrm{~Hz}, 2 \mathrm{H}), 2.62(\mathrm{t}, J=7.4 \mathrm{~Hz}, 2 \mathrm{H}) ; \mathrm{MS}: m / z$ $=131.1\left[\mathrm{M}^{+}\right]$.

Dodecanenitrile (25b). Colorless oil; ${ }^{1} \mathrm{H} \mathrm{NMR}\left(500 \mathrm{MHz}, \mathrm{CDCl}_{3}\right)$ $\delta 2.33(\mathrm{t}, J=7.1 \mathrm{~Hz}, 2 \mathrm{H}), 1.66-1.62(\mathrm{~m}, 2 \mathrm{H}), 1.47-1.41(\mathrm{~m}, 2 \mathrm{H}), 1.29-$ $1.27(\mathrm{~m}, 12 \mathrm{H}), 0.87$ (t, $J=7.0 \mathrm{~Hz}, 3 \mathrm{H})$; MS: $m / z=162.1\left[\mathrm{M}^{+}\right]$.

1,3-Benzodioxole-5-propanenitrile (26b). Pale yellow oil; ${ }^{1} \mathrm{H}$ NMR (500 MHz, $\left.\mathrm{CDCl}_{3}\right) \delta 6.77(\mathrm{~d}, J=7.9 \mathrm{~Hz}, 1 \mathrm{H}), 6.72(\mathrm{~d}, J=$ $1.6 \mathrm{~Hz}, 1 \mathrm{H}), 6.69-6.67(\mathrm{~m}, 1 \mathrm{H}), 5.93$ (s, 2H), 2.85-2.73 (m, 3H), $1.31(\mathrm{~d}, J=6.7 \mathrm{~Hz}, 3 \mathrm{H})$; MS: $m / z=189.1\left[\mathrm{M}^{+}\right]$.

$\boldsymbol{N}$-Boc-4-piperidinecarbonitrile (27b). Colorless oil; ${ }^{1} \mathrm{H}$ NMR $\left(500 \mathrm{MHz}, \mathrm{CDCl}_{3}\right) \delta 3.68-3.31(\mathrm{~m}, 4 \mathrm{H}), 2.82-2.77(\mathrm{~m}, 1 \mathrm{H}), 1.90-$ $1.75(\mathrm{~m}, 4 \mathrm{H}), 1.45$ (s, 9H); MS: $m / z=209.2\left[\mathrm{M}^{+}\right]$.

Cinnamonitrile (28b). Pale yellow oil; ${ }^{1} \mathrm{H}$ NMR $(500 \mathrm{MHz}$, $\left.\mathrm{CDCl}_{3}\right) \delta 7.47-7.39(\mathrm{~m}, 6 \mathrm{H}), 5.89(\mathrm{~d}, J=16.7 \mathrm{~Hz}, 1 \mathrm{H})$; MS: $m / z=$ $129.0\left[\mathrm{M}^{+}\right]$.

$\alpha$-Methylcinnamonitrile (29b). Pale yellow oil; ${ }^{1} \mathrm{H}$ NMR (500 $\left.\mathrm{MHz}, \mathrm{CDCl}_{3}\right) \delta$ 7.43-7.42 (m, 2H), 7.40-7.38 (m, 1H), 7.35-7.34 $(\mathrm{m}, 2 \mathrm{H}), 7.23(\mathrm{~d}, J=0.5 \mathrm{~Hz}, 1 \mathrm{H}), 2.16$ (d, $J=1.6 \mathrm{~Hz}, 3 \mathrm{H}) ; \mathrm{MS}: m / z$ $=143.1\left[\mathrm{M}^{+}\right]$.

4-(4-Cyano-3-(p-tolyl)-1H-pyrazol-1-yl)benzenesulfonamide (30b). White solid; ${ }^{1} \mathrm{H}$ NMR (500 MHz, DMSO- $\left.d_{6}\right) \delta 9.55(\mathrm{~s}, 1 \mathrm{H})$, $8.15(\mathrm{~d}, J=8.8 \mathrm{~Hz}, 2 \mathrm{H}), 8.02(\mathrm{~d}, J=8.8 \mathrm{~Hz}, 2 \mathrm{H}), 7.90(\mathrm{~d}, J=$ $8.1 \mathrm{~Hz}, 2 \mathrm{H}), 7.51(\mathrm{~s}, 2 \mathrm{H}), 7.41(\mathrm{~d}, J=8.0 \mathrm{~Hz}, 2 \mathrm{H}), 2.40(\mathrm{~s}, 3 \mathrm{H})$; MS (ESI): $m / z=360.3(\mathrm{M}+\mathrm{Na})^{+}$.

\section{Acknowledgements}

This work was financially supported by the National Natural Science Foundation of China (21376224, 21206147), the Natural
Science Foundation of Zhejiang Province (LY17B060007), and Hangzhou Qianjiang Distinguished Experts Project.

\section{Notes and references}

1 A. R. Katritzky, B. Pilarski and L. Urogdi, Synthesis, 1989, 949-950.

2 J. Borau-Garcia, D. V. Gutsulyak, R. J. Burford and W. E. Piers, Dalton Trans., 2015, 44, 12082-12085.

3 C. Battilocchio, J. M. Hawkins and S. V. Ley, Org. Lett., 2014, 16, 1060-1063.

4 F. Gould, G. Johnson and A. Ferris, J. Org. Chem., 1960, 25, 1658-1660.

5 H. Adkins and H. R. Billica, J. Am. Chem. Soc., 2002, 1948(70), 695-698.

6 W. B. Jang, W. S. Shin, J. E. Hong, S. Y. Lee and D. Y. Oh, Synth. Commun., 2006, 27, 3333-3339.

7 M. Ortiz-Marciales, L. M. Tirado, R. Colon, M. L. Ufret, R. Figueroa, M. Lebron, M. DeJesus, J. Martinez and T. Malave, Synth. Commun., 1998, 28, 4067-4075.

8 D. Brady, N. Dube and R. Petersen, S. Afr. J. Sci., 2006, 102, 339-344.

9 J. Raj, N. Singh, S. Prasad, A. Seth and T. C. Bhalla, Acta Microbiol. Immunol. Hung., 2007, 54, 79-88.

10 T. Kamitanaka, K. Yamamoto, T. Matsuda and T. Harada, Tetrahedron, 2008, 64, 5699-5702.

11 M. Noe, A. Perosa and M. Selva, Green Chem., 2013, 15, 22522260.

12 D. J. Augeri, J. A. Robl, D. A. Betebenner, D. R. Magnin, K. Ashish, J. G. Robertson, W. Aiying, L. M. Simpkins, T. Prakash and H. Qi, J. Med. Chem., 2005, 48, 5025-5037.

13 E. Pascual, F. Sivera, U. Yasothan and P. Kirkpatrick, Nat. Rev. Drug Discov., 2009, 8, 191-192.

14 H. Jiang, X. Yang, Z. Cui, Y. Liu, H. Li, W. Hu, Y. Liu and D. Zhu, Appl. Phys. Lett., 2007, 91, 123505, DOI: 10.1063/ 1.2784970 .

15 D. T. Mowry, Chem. Rev., 1948, 42, 189-283.

16 G. P. Ellis and T. M. Romney-Alexander, Chem. Rev., 1987, 87, 779-794.

17 S. U. Dighe, D. Chowdhury and S. Batra, Adv. Synth. Catal., 2014, 356, 3892-3896.

18 R. V. Jagadeesh, H. Junge and M. Beller, Nat. Commun., 2014, 5, 4123, DOI: 10.1038/ncomms5123.

19 W. Yin, C. Wang and Y. Huang, Org. Lett., 2013, 15, 18501853.

20 D.-W. Tan, J.-B. Xie, Q. Li, H.-X. Li, J.-C. Li, H.-Y. Li and J.-P. Lang, Dalton Trans., 2014, 43, 14061-14071.

21 T. Oishi, K. Yamaguchi and N. Mizuno, Angew. Chem., Int. Ed., 2009, 48, 6286-6288.

22 L. Gao, H. Tang and Z. Wang, Chem. Commun., 2014, 50, 4085-4088.

23 K. M. Lambert, J. M. Bobbitt, S. A. Eldirany, K. B. Wiberg and W. F. Bailey, Org. Lett., 2014, 16, 6484-6487.

24 A. F. Shoair and A. A. El-Bindary, Spectrochim. Acta, Part A, 2014, 131, 490-496.

25 D. Damodara, R. Arundhathi and P. R. Likhar, Adv. Synth. Catal., 2014, 356, 189-198. 
26 S. Zhou, D. Addis, S. Das, K. Junge and M. Beller, Chem. Commun., 2009, 4883-4885.

27 S. Elangovan, S. Quintero-Duque, V. Dorcet, T. Roisnel, L. Norel, C. Darcel and J.-B. Sortais, Organometallics, 2015, 34, 4521-4528.

28 S. Itagaki, K. Kamata, K. Yamaguchi and N. Mizuno, ChemCatChem, 2013, 5, 1725-1728.

29 X. Zhang, J. Sun, Y. Ding and L. Yu, Org. Lett., 2015, 17, 58405842.

30 L. Yu, H. Li, X. Zhang, J. Ye, J. Liu, Q. Xu and M. Lautens, Org. Lett., 2014, 16, 1346-1349.

31 M. B. Erman, J. W. Snow and M. J. Williams, Tetrahedron Lett., 2000, 41, 6749-6752.

32 S. Talukdar, J. L. Hsu, T. C. Chou and J. M. Fang, Tetrahedron Lett., 2001, 42, 1103-1105.

33 H. Sharghi and M. H. Sarvari, ChemInform, 2003, 34, 1032310328.

34 B. Movassagh and S. Shokri, Tetrahedron Lett., 2005, 46, 6923-6925.

35 S. Laulhe, S. S. Gori and M. H. Nantz, J. Org. Chem., 2012, 77, 9334-9337.

36 M. Sridhar, M. K. K. Reddy, V. V. Sairam, J. Raveendra, K. R. Godala, C. Narsaiah, B. C. Ramanaiah and C. S. Reddy, Tetrahedron Lett., 2012, 53, 3421-3424.

37 B. V. Rokade and K. R. Prabhu, J. Org. Chem., 2012, 77, 53645370.

38 J. Nagarkar, U. Patil and S. Shendage, Synthesis, 2013, 45, 3295-3299.
39 H. Veisi, Synthesis, 2010, 2631-2635.

40 C. Tao, F. Liu, Y. Zhu, W. Liu and Z. Cao, Org. Biomol. Chem., 2013, 11, 3349-3354.

41 J. N. Noh and J. Kim, J. Org. Chem., 2015, 80, 11624-11628.

42 C. B. Kelly, K. M. Lambert, M. A. Mercadante, J. M. Ovian, W. F. Bailey and N. E. Leadbeater, Angew. Chem., Int. Ed., 2015, 54, 4241-4245.

43 M. Waterman, J. Knight, J. M. Stempak, K. Croitoru, G. C. Nguyen, Z. Cohen, R. S. Mcleod, G. R. Greenberg, A. H. Steinhart and M. S. Silverberg, RSC Adv., 2013, 3, 1311-1316.

44 Y. Zi, Z. J. Cai, S. Y. Wang and S. J. Ji, Org. Lett., 2014, 16, 3094-3097.

45 X. Zhang and L. Wang, Green Chem., 2012, 14, 2141-2145.

46 H. Jiang, H. Huang, H. Cao and C. Qi, Org. Lett., 2010, 12, 5561-5563.

47 K. Rajender Reddy, C. Uma Maheswari, M. Venkateshwar, S. Prashanthi and M. Lakshmi Kantam, Tetrahedron Lett., 2009, 50, 2050-2053.

48 Y. Wei, C. Zhu and C. Sun, Synthesis, 2010, 4235-4241.

49 G. Bagherzade, A. Zali and A. Shokrolahi, Chin. Chem. Lett., 2015, 26, 603-606.

50 C. Fang, M. Li, X. Hu, W. Mo, B. Hu, S. Nan, L. Jin and Z. Shen, Adv. Synth. Catal., 2016, 358, 1157-1163.

51 Q. Chen, C. Fang, Z. Shen and M. Li, Electrochem. Commun., 2016, 64, 51-55.

52 S. Yi, M. Li, W. Mo, X. Hu, B. Hu, N. Sun, L. Jin and Z. Shen, Tetrahedron Lett., 2016, 57, 1912-1916. 